\title{
MOLECULAR MONITORING OF BACTERIAL AND MICROALGAL BIOCENOSES' BIODIVERSITY IN HIGH LOADED FARMING PONDS
}

\author{
ANALIZA BIORÓŻNORODNOŚCI BIOCENOZY BAKTERYJNEJ I GLONOWEJ \\ W SILNIE OBCIĄŻONYCH STAWACH HODOWLANYCH
}

\begin{abstract}
Eutrophication process is a serious problem in water ecosystems. There is a great need to study the relation between the physico-chemical condition of water and the influence of these parameters on the diversity of biological life, especially on changes in the structure of microbiocenoses. The most interesting are bacteria and microalgae, due to the important roles they play in maintaining the balance of the aquatic environment. In this study, biodiversity analysis of eukaryotic microalgae and bacteria in two artificial water ecosystems - fish farming ponds - was performed. Aquaculture was based on IMTA technology, in which every part of the trophic chain plays a significant role in maintaining the balance in the ecosystems. Experimental intensive - extensive systems differed in terms of nutrient loads, ponds were characterized by high loads of organic and inorganic nitrogen and phosphorus. During the experimental period, the physicochemical conditions, quantitative genotypic structure of the two biocenoses being studied and the relation between these factors were monitored and investigated. For the biodiversity analysis, the PCR - DGGE technique was used. The results of preliminary research showed that there is a correlation between nutrient loads, diversity expressed in the Shannon-Wiener Index and the overall condition of experimental systems. Higher loadings of nutrient promote the development of bacteria and microalgae without any influence on the balance in the artificial ecosystem being tested.
\end{abstract}

Keywords: bacteria, microalgae, biodiversity, eutrophication, Shannon-Wiener Index, fish farming ponds

\section{Introduction}

Eutrophication of natural surface water is a widely discussed problem in developed countries. Its implications and the methods for prevention and mitigation of this phenomenon are the subject of many studies. Globalisation, intensive agricultural production with fertilization assistance, and irrational water and sewage management all

\footnotetext{
${ }^{1}$ Environmental Biotechnology Department, The Silesian University of Technology, ul. Akademicka 2A, 44-100 Gliwice, Poland, phone +48 3223729 15, fax +48 3223729 46, email: Agata.Karlo@polsl.pl, Aleksandra.Ziembinska-Buczynska@polsl.pl, Joanna.S.Gorska@polsl.pl

${ }^{2}$ The Institute of Ichthyobiology and Aquaculture of the Polish Academy of Sciences, ul. Kalinowa 2, 43-520 Chybie, phone +48 3385615 51, fax +48 3385892 92, email: maciej.pilarczyk@ golysz.pan.pl

*Corresponding author: Agata.Karlo@polsl.pl
} 
cause an excessive environmental burden. The EU Water Framework Directive (WFD, European Union, 2000) and the EU Bathing Water Directive (BWD, European Union, 2006) demand proactive management of the relevant waters to maintain good quality. This approach requires effective and reliable measures for monitoring eutrophication [1]. A high nutrient load is the major cause of eukaryotic microalgae and cyanobacteria water blooms, which are associated with oxygen deficiency and the presence of toxins harmful to aquatic organisms. Water blooms may cause increased water turbidity and odour. Algal and cyanobacteria blooms may lead to oxygen deficiency, thus causing fish mortality. On the other hand, as a part of the ecosystem in which microalgae are primary producers, they also play a major role in the circulation of elements in the food chain. Furthermore, bacterioplankton is a major biological component in the transformation and mineralization of the organic matter in aquatic systems [2,3]. Quality monitoring of these two groups of microorganisms, which are responsible for maintaining ecosystems' homeostasis, is an important tool enabling visualization of ecological dependences within algal and bacterial communities and detection of abnormal environmental conditions on their structures. The presence of nutrients, especially high loads of phosphorus and nitrogen, play a crucial role in the eutrophication process. Interactions among nutrients, producers and consumers remain poorly understood for most aquatic ecosystems.

One method which is very useful in studying the structure of micro communities such like bacteria and eukaryotic microalgae is PCR-DGGE (denaturing gradient gel electrophoresis). This type of electrophoresis uses differences in the melting temperatures $\left(T_{m}\right)$ of double-stranded DNA. The process is carried out in polyacrylamide gel containing an increasing gradient of denaturant. Nucleic acid fragments are previously amplified by PCR (polymerase chain reaction) and they differ only in the sequence, as they are the same in length. During electrophoresis the hydrogen bonds are broken and partially single-stranded molecules with reduced electrophoretic mobility (retarded) are formed. This provides a separation of DNA fragments which have the same gel mobility in double-stranded forms in a non-denaturing environment, but different melting properties (based on the difference in sequence) [4]. This technique is repeatable, fast, highly sensitive, relatively cheap and commonly used in environmental samples analyses, ie microbial communities in different types of freshwater aquatic biosystems [5-8].

The aim of this experiment was to compare the composition and changeability of bacterial and microalgal communities in two fish farming ponds, under the controlled conditions of the eutrophication process. The PCR-DGGE method was used for this purpose.

\section{Materials and methods}

\section{Site description and sampling}

The experiment was conducted at the Institute of Ichthyobiology and Aquaculture of the Polish Academy of Sciences located in southern Poland. Water has been sampled from two experimental ponds being a part of an experimental integrated, intensive-extensive aquaculture systems based on IMTA (Integrated Multi-Trophic Aquaculture) concept. Each pond was $\sim 1800 \mathrm{~m}^{2}$ in area and $1.2 \mathrm{~m}$ deep. The ponds were characterized by a high load of nutrients and organic compounds derived from fish fodder and metabolic products of intensive subsystem. The systems differed in terms of organic matter load (stable throughout 
the experimental period). The system with a normal load was identified as "A", while the system with a doubled load identified as "B".

Water samples were collected from July to October 2013, as the ponds were filled until the end of the experiment, at two-week intervals. There were thirteen samples in total during the vegetation season. In Central Europe these months are characterized by an air temperature ranging from 15 to $30^{\circ} \mathrm{C}$ and high insolation, thus environmental conditions are favourable to algal blooms. Water was stored in plastic bottles at $4{ }^{\circ} \mathrm{C}$ and transported to the laboratory within a few hours. $150 \mathrm{~cm}^{3}$ of water was filtered with a sterile filtration unit (Merck Millipore) over a $0.2 \mu \mathrm{m}$ pore-size membrane, through polycarbonate filters (Whatman). The filters were then divided into 4 parts, placed in falcon-type tubes and stored at $45^{\circ} \mathrm{C}$ for further processing.

\section{Physicochemical variables}

Chemical oxygen demand (COD) and nutrient concentrations (Kjeldahl nitrogen, $\mathrm{NH}_{4}{ }^{+}$, $\mathrm{NO}_{3}{ }^{-}, \mathrm{PO}_{4}{ }^{3-}$ and total phosphorus) were measured in the water during the experimental period, in accordance with Polish Norms (PN-EN 25663, PN-C-04576-4, PN-EN ISO 10304-1, PN-EN ISO 6878, PN-74/C-04578, PN-EN ISO 6878). Chlorophyll A content was checked spectrophotometrically with extraction in acetone to monitor the increase in algae biomass. Parameters like water temperature and oxygen concentration were also measured.

\section{Molecular analyses}

Genetic material from frozen filtered samples was isolated using a commercial GeneMATRIX Soil DNA Purification Kit (EURx), according to manufacturer's instructions. Polymerase chain reactions were performed using two primer sets, which code universal bacterial and eukaryotic molecular markers (16S rRNA and 18S rRNA gene fragment, respectively). The sequences of the primers are presented in Table 1.

Table 1

Primer sequence used to amplify bacterial and microalgal DNA

\begin{tabular}{|c|c|c|c|}
\hline $\begin{array}{c}\text { Target } \\
\text { organisms }\end{array}$ & Primer & Sequence & Reference \\
\hline \multirow{3}{*}{ Bacteria } & $518 \mathrm{r}$ & ATT-ACC-GCG-GCT-GCT-GG & \multirow{2}{*}[9]{} \\
\cline { 2 - 4 } & $338 \mathrm{f}-(\mathrm{GC})$ & $\begin{array}{r}\text { (CGC-CCG-CCG-CGC-GCG-GCG-GGC-GGG-GCG-GGG-GCA- } \\
\text { CGG-GGG-GCC)-TAC-GGG-AGG-CAG-CAG }\end{array}$ & \multirow{2}{*}{ Co] } \\
\hline \multirow{3}{*}{ Microalgae } & Euk1A & CTG-GTT-GATCCT-GCC-AG & \\
\cline { 2 - 4 } & Euk516r-(GC) & $\begin{array}{r}\text { ACC-AGA-CTT-GCC-CTC-C-(CGC-CCG-CCG-CGC-GCG- } \\
\text { GCG-GGC-GGG-GCG-GGG-GCA-CGG-GGG-G) }\end{array}$ & \\
\hline
\end{tabular}

The amplification of gene fragments being analysed was performed in a $\mathrm{C} 1000^{\mathrm{TM}}$ thermal cycler (BioRad) in a $30 \mathrm{~mm}^{3}$ reaction volume containing $1.5 \mathrm{U}$ GoTaq Flexi Polymerase (Promega), $1 \times$ buffer, $2 \mathrm{mM} \mathrm{MgCl} 2,5 \mathrm{pmol} / \mathrm{mm}^{3}$ of each primers, $20 \mathrm{pmol} / \mathrm{mm}^{3}$ of dNTPs and $0.5 \mathrm{~mm}^{3}$ or $1 \mathrm{~mm}^{3}$ of template DNA (for bacteria and microalgae, respectively). The temperature cycling conditions for the amplification of the genes in question were previously described by Muyzer et al [9] and Eland et al [11]. PCR products were evaluated in $1 \%$ agarose gel electrophoresis with a $1 \mathrm{~kb}$ DNA Ladder (Promega) and visualized under UV light. 
The DGGE of the PCR products obtained in reactions with 338F-GC/518R and Euk1A/Euk516r-GC primers underwent electrophoretic separation in the Dcode Universal Mutation Detection System (BioRad). Polyacrylamide gel (8\%, 37:1 acrylamide-bisacrylamide, Fluka) with a gradient of 30-60\% denaturant was prepared according to the manufacturer's instruction. Electrophoresis was performed in a $1 \times \mathrm{TAE}$ buffer at a constant temperature of $60^{\circ} \mathrm{C}$ for 16 hours at $40 \mathrm{~V}$. Gels were stained with SYBR Gold (1:10 000, Invitrogen) in MiliQ water for $30 \mathrm{~min}$ and distained in MiliQ water for the next $30 \mathrm{~min}$, then visualized under UV light and photographed using Quantity One 1D (BioRad).

\section{Statistical analyses}

The analysis of DGGE fingerprints was performed using Quantity One 1D software (BioRad). Bacterial biodiversity was estimated on the basis of densitometric measurements and the Shannon-Wiener diversity index, and calculated as follows (equation (1)) using the relative intensity of bands in each sample:

$$
H^{\prime}=-\sum p_{i} \ln p_{i}
$$

where: $H^{\prime}$ - species diversity index, $p_{i}$ - the relative contribution of band $i$ intensity to the total band intensities for whole lane.

On the basis of the PCR-DGGE fingerprints, the dendrograms using the Neighbor Joining with Dice coefficient method were built. Analysis was designed for both pairs of the primers. The number of OTUs (Operational Taxonomic Units) was defined as the number of lanes in the gel.

\section{Results}

\section{Physico-chemical and biological characteristics of experimental ponds}

The seasonal fluctuations in temperature and oxygen concentrations shown in Figure 1, were similar in both systems. Physicochemical and biological parameters like $\mathrm{N}-\mathrm{NH}_{4}$, $\mathrm{N}-\mathrm{NO}_{3}$, Kjeldahl nitrogen, $\mathrm{P}-\mathrm{PO}_{4}$, total phosphorus, oxygen, COD concentrations, temperature and chlorophyll A content are illustrated in Figures 2-5. At the beginning of the experiment, ponds were differentiated by $\mathrm{N}_{-} \mathrm{NH}_{4}, \mathrm{~N}-\mathrm{NO}_{3}$ and total phosphorus concentration, which is correlated with a varying load of organic matter. After a week (adaptation phase), the value of the $\mathrm{N}^{-\mathrm{NH}_{4}}$ parameter stabilized in both systems and fluctuated between 0.04 and $0.13 \mathrm{mg} / \mathrm{dm}^{3}$. The $\mathrm{NO}_{3}$ concentration from day 50 of the experiment was higher in system " $\mathrm{B}$ ". During the remaining period, the values obtained were similar and fluctuated between 0.1 and $0.4 \mathrm{mg} / \mathrm{dm}^{3}$. The Kjeldahl nitrogen concentration in both systems was maintained at a comparable level, but after day 57 the concentration decreased in system "B". Analysis of total phosphorus concentrations showed that in system " $B$ ", the value of this parameter during the entire experimental period was higher, but the differences weren't significant. In turn, from the beginning to the 35 th day of the experiment, the differences in phosphate concentrations between the systems were visible. In the double-loaded pond this parameter value changed dynamically and it was higher than in the single-loaded pond. Chemical oxygen demand (COD) was lower in system "B" than in "A". Chlorophyll A content growth in water samples was correlated with a temperature increase but in system "B" it was higher (it reached $166 \mathrm{mg} / \mathrm{dm}^{3}$ ). 
a)

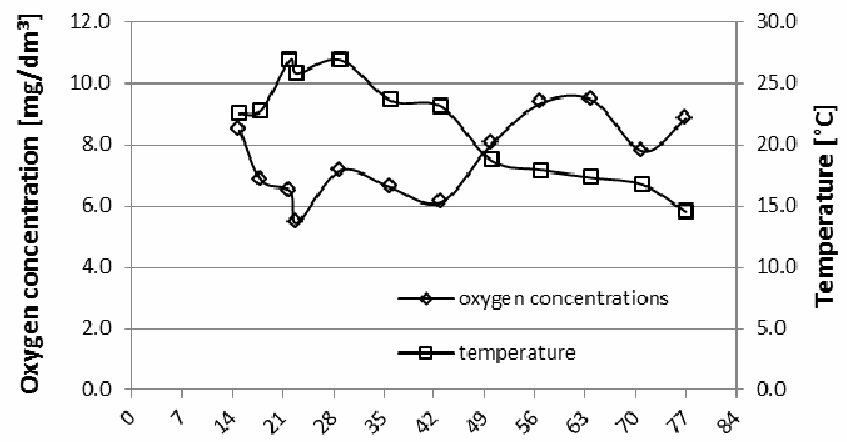

b)

Day of experiment

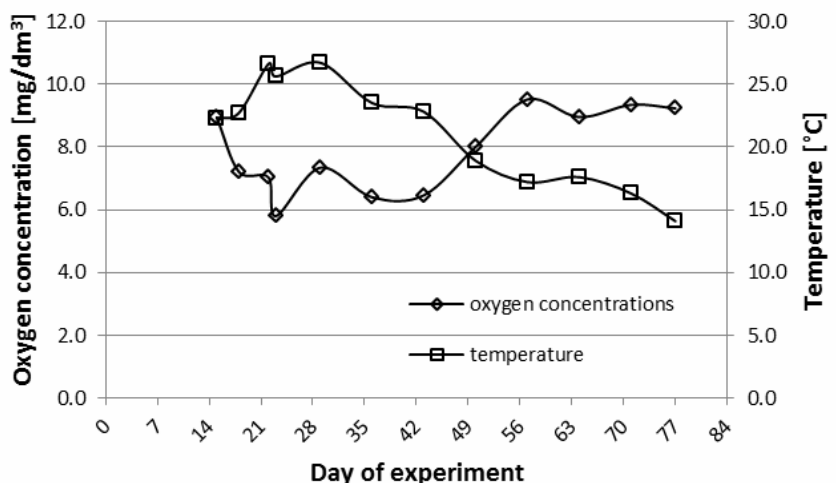

Fig. 1. Temperature and oxygen concentration changes in experimental ponds between July and October 2013

a)
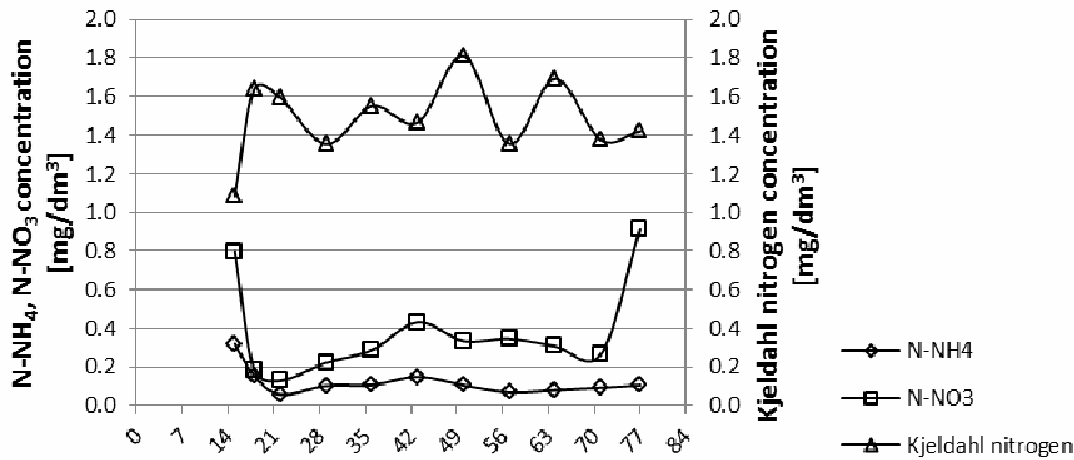

Day of experiment 
b)
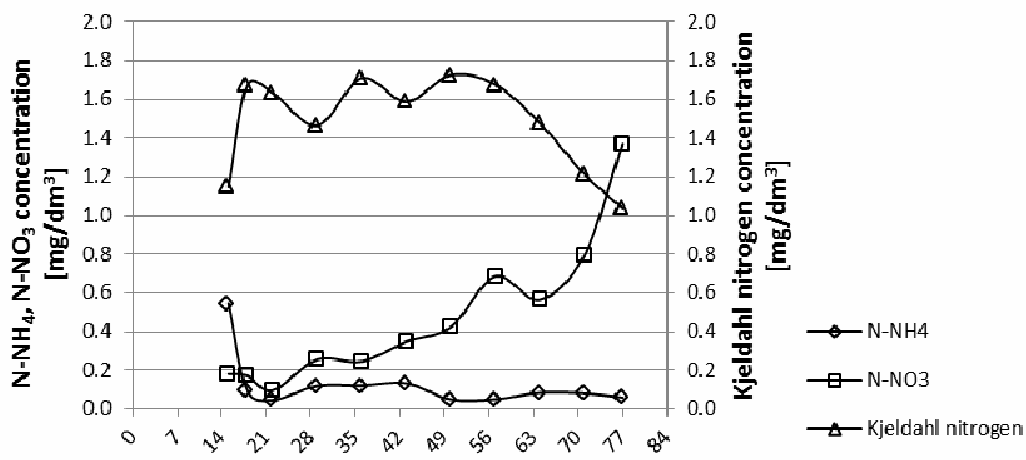

Day of experiment

Fig. 2. Nitrogen forms concentration changes in experimental ponds between July and October 2013

a)

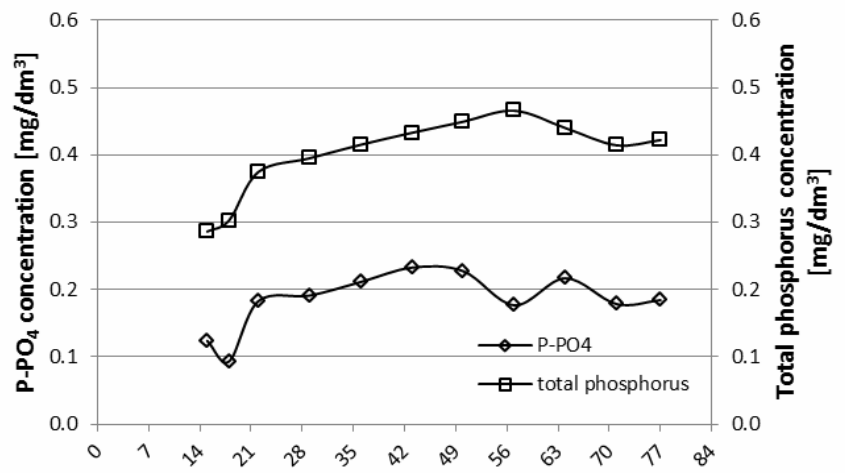

b)

Day of experiment

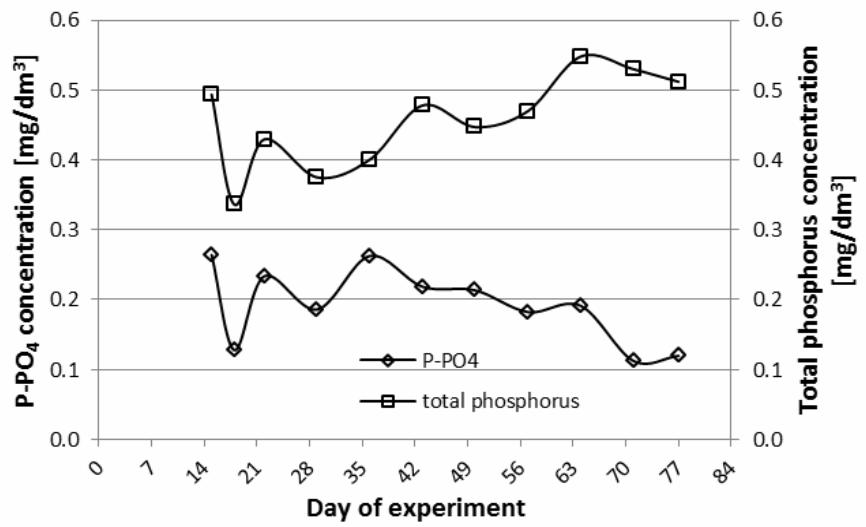

Fig. 3. Phosphates and total phosphorus concentrations in experimental ponds between July and October 2013 


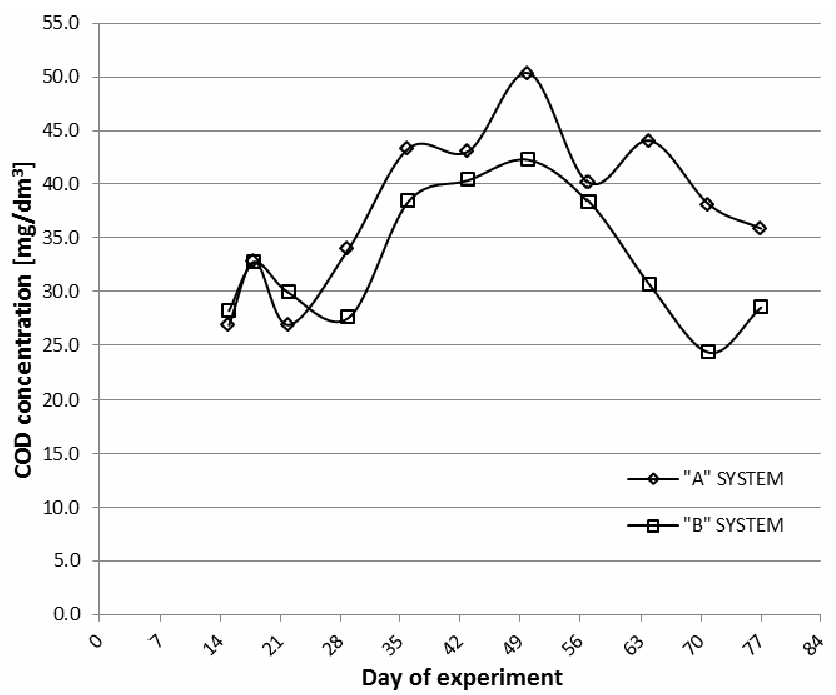

Fig. 4. COD concentration changes in experimental ponds between July and October 2013

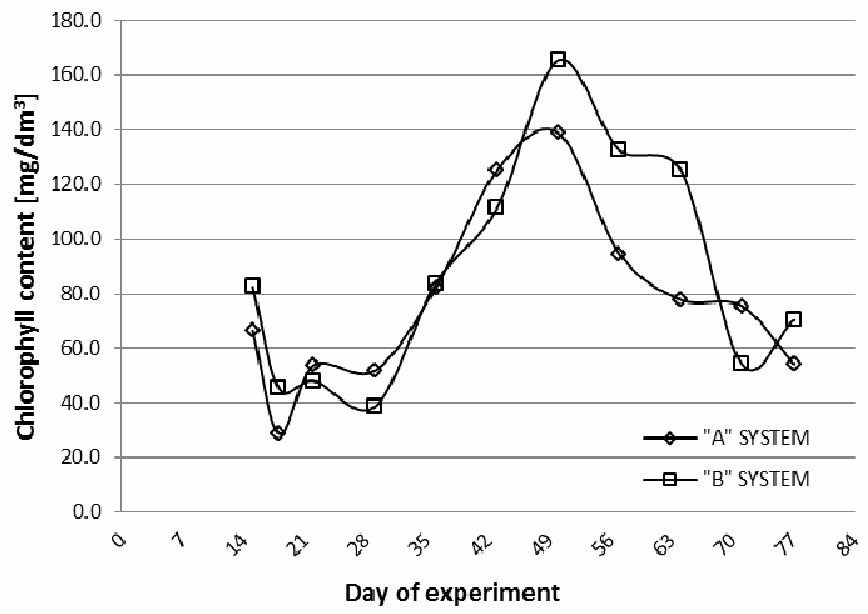

Fig. 5. Chlorophyll content in experimental ponds between July and October 2013

\section{Bacterial and microalgal community structure}

The analysis of the bacterial and microalgal community was performed for the entire duration of the experiment in two intensive-extensive fish farming systems differing in nutrient loads. For both systems bacterial and microalgal biocenoses were monitored with PCR-DGGE. The DGGE monitoring of the total bacterial community with $338 \mathrm{f}-\mathrm{GC}$ and 518r primers is presented in Figure 6. The Shannon biodiversity index was calculated on the basis of the DGGE fingerprint densitometric analysis and presented in Figure 7. 


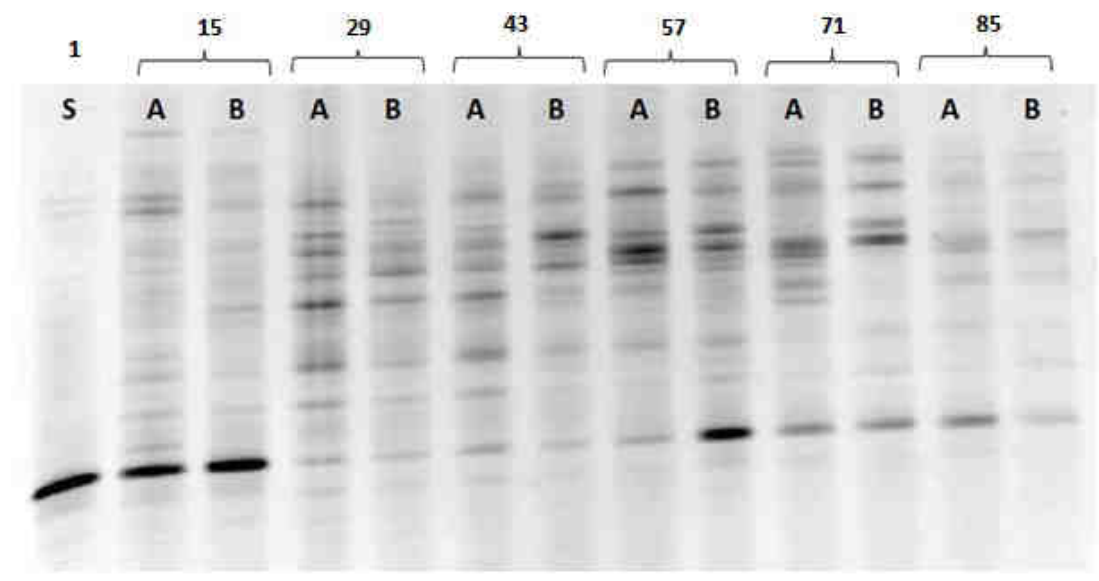

Fig. 6. DGGE fingerprints for $180 \mathrm{bp}$ amplicons in experimental ponds (S - start day)

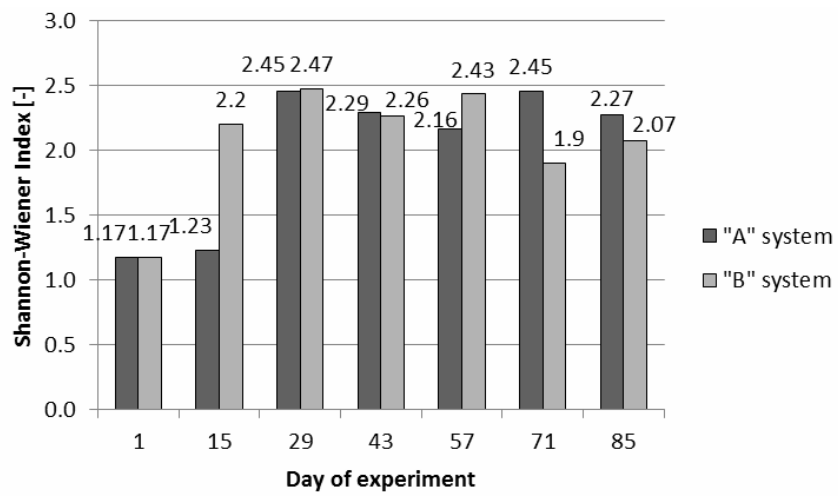

Fig. 7. Bacterial biodiversity index estimated on the basis of DGGE results for fragments amplified with 338f-GC and 518r

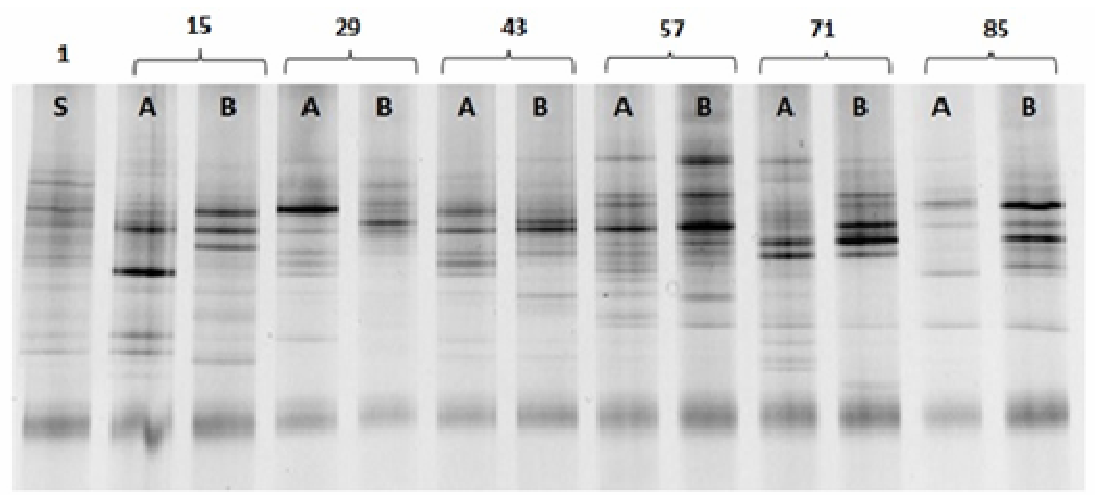

Fig. 8. DGGE fingerprints for $560 \mathrm{bp}$ amplicons in experimental ponds (S - start day) 


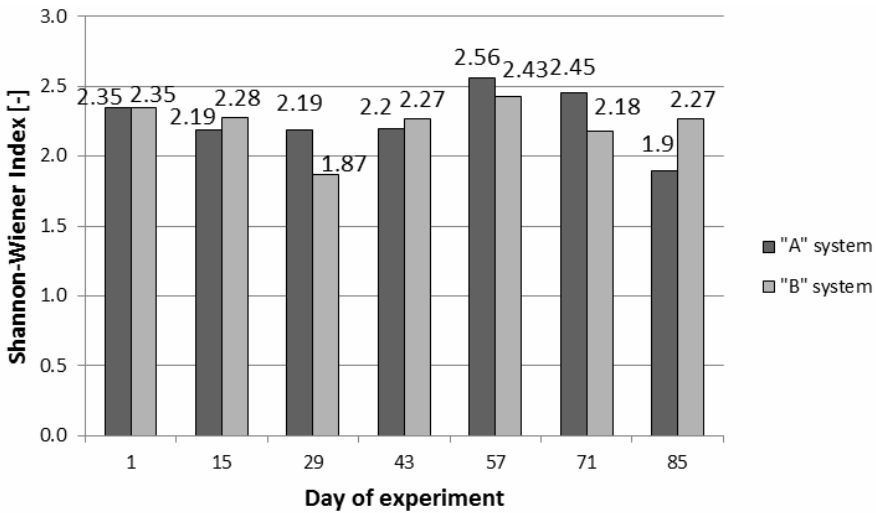

Fig. 9. Eukaryotic microorganisms biodiversity index estimated on the basis of DGGE results for fragments amplified with Euk1A and Euk516r-GC

a)

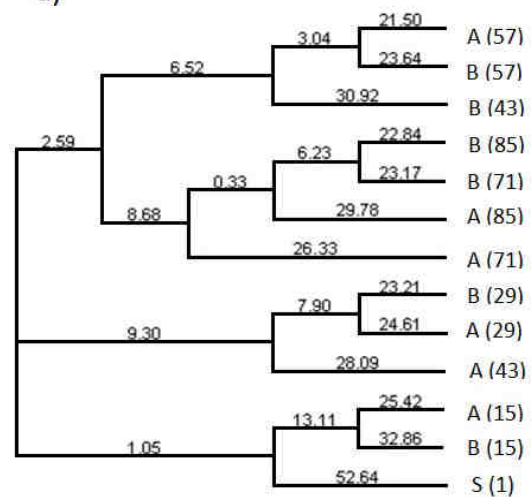

b)

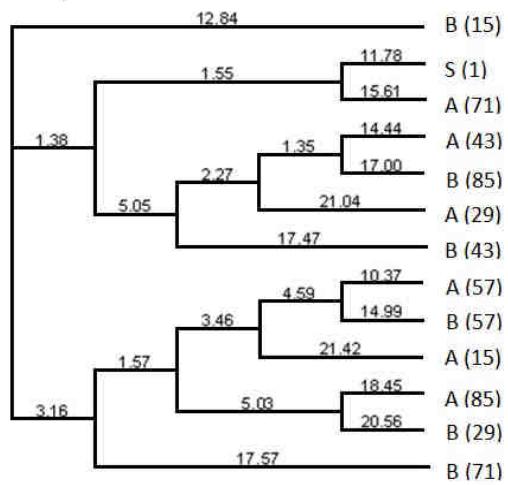

Fig. 10. The dendrogram presenting the similarity of PCR-DGGE fingerprints constructed using Neighbor Joining method obtained for 180 bp PCR products for all bacteria (a); 560 bp PCR products for microalgae (b) (Dice coefficient in dendrogram's nodes, day of experiment in brackets, A - single load pond, B - double load pond)

The DGGE monitoring of the microalgae community with Euk1A and Euk516r-GC primers is presented in Figure 8. The Shannon biodiversity index for these fingerprints is illustrated in Figure 9. The results of Neighbor-Joining clustering of the fingerprints received are showed on dendrograms in Figure 10.

\section{Discussion}

The experiment showed that both bacterial and algal microbiocenoses genotypic structures are dynamically remodelled during a pond's vegetation season. This suggests that communities adapt to changing environmental conditions. Bacterial biocenosis at the beginning of the experiment was poor, which is related to the type of water used. Ponds were filled with water from the River Vistula (at approximately 40 kilometers of its 
1047 kilometer length), and the water was subsequently directed via 7 kilometers of drainage ditches to the destination point. Water from this part of river, called Little Vistula, is oligotrophic and characterized by low biodiversity. This fact is connected with unstable environmental conditions - ie low temperatures, mixing, low nutrient loads and its origin (the source is a mountain stream flowing out of the Beskid Mountains in Southern Poland).

After two weeks of the experiment, the first changes in the genotypic structure of the bacterial communities were observed. In system "B", which had a double load of organic nitrogen, biodiversity and Shannon-Wiener Index was much higher than in system "A". The ammonium nitrogen concentration at this point of the experiment was also higher. One month after the start of the experiment, the biological situation in both systems was comparable. The biodiversity Index was lower, and the ammonium nitrogen concentration was reduced to a level of $0.05-0.015 \mathrm{mg} / \mathrm{dm}^{3}$ with a simultaneous increase in the nitrate concentration (higher in system "B"). These observations suggest the possible occurrence of a nitrification process. On day 71 of the experiment, the bacterial community structure rebuilt again. The number of bands in system " $B$ " was smaller, while the concentration of ammonium nitrogen had also decreased.

COD analyses showed that in system "B", organic compounds were removed more efficiently than in system "A". The differences in the concentrations weren't high, but during the entire experimental period the trend was visible. This indicates that heterotrophic bacteria are numerously present and more active in this biocenosis structure. This also showed that eutrophication enhances the biogeochemical cycle of organic compounds and contaminants, which was previously demonstrated in the example of PCB (polychlorinated biphenyles) contamination [12].

Bands in fingerprints are localized mainly in the upper and middle parts of the gel, thus the bacterial genotypes which dominated in both systems had a low and average $\mathrm{G}+\mathrm{C}$ content (which is related to a low melting temperature and retardation time, while genotypes rich in $\mathrm{G}+\mathrm{C}$ have a high melting temperature and migrate in gel longer). This information may be useful and will be taken into account in the next season of the experiment. Literature sources showed that species such as Alcaligenes, Bacillus, Flavobacterium, Vibrio, Pseudomonas and Clostridium are typical for stagnant freshwater and are present in aquatic systems in the Middle-European climate. Assuming some similarities between experimental ponds and lakes, it can be supposed that they were present in research systems. However, this hypothesis requires conformation by other methods. Of special interest is the Flavobacterium species, due to the fact that these bacteria are natural symbionts of fish mucus. Under altered environmental conditions during water eutrophication, their bacteriological index increases, which adversely affects the health of fish (it may cause problems with the gills and lead to death). This type of problem has appeared, but without the phenomenon of oxygen deficiency. Typically, this is the reason for fish death.

Dendrograms based on bacterial fingerprints reveal some trends in the changeability of these biocenoses. It can be noticed that samples from system "B", taken after a month after the start day are more similar to the samples from system " $A$ " from the next measuring day than to samples from the same day. It was shown that in the double-loaded pond, bacterial biocenosis converted more rapidly than in the single-loaded pond. It also showed that higher nutrient concentrations promote increases in biodiversity.

The biodiversity of eukaryotic microorganisms is comparable in both systems, and stable during the season. Between day 30 and day 60 of the experiment, the biodiversity 
decreased, which is presented as an increase in chlorophyll content and related to phosphate concentrations, which decrease as a result of incorporation into biomass. These data showed that the bloom of microalgae probably appears. The number of genotypes was lower at this time, certain genotypes dominated in both communities. This is visible in both systems, but in system "B" this phenomenon occurred more intensively. The dendrogram also showed that microalgal biocenoses in both systems rebuild dynamically. The dendrogram consisted of three main branches, but we found no specific dependences between the samples in its structure. This confirms the conclusion about the high changeability of this biocenosis during the experimental period.

The PCR-DGGE method is useful for qualitative study of the biodiversity of environmental communities, but it is not free of analytical errors. Firstly, it is very important to compare fingerprints received from samples with statistical data expressed as $H^{\prime}$. As it is shown in the case of microalgae, the Shannon-Wiener Index is similar in both systems, but from the picture of the gel it is clear that these biocenoses were not stable, but were rebuilt dynamically during the whole experiment. Secondly, the main disadvantage of this technique is that it gives only partial information about microbial diversity, since the number of bands is related to the number of populations that may account for more than 0.3 to $0.4 \%$ of the total cell counts [5]. This is due to comigration of amplicons (PCR products) from different species within the same band and conversely, one species can have more than one genotype and give several bands [13]. Some authors also note the subjectivity in deciding whether a very weak band is a real band or a background artefact [14]. Despite these objections, the PCR-DGGE method enables general quality monitoring of the group of microorganisms studied and changes in their composition over time. Thus, this is a very useful tool for studying the influence of environmental conditions and factors which disrupt the balance in the ecosystems on its microstructure.

\section{Conclusions}

The experiment showed some ecological dependence between the nutrient loads and the qualitative composition of two main microbiocenoses in aquatic biosystems. Monitoring of physicochemical and biological parameters led to the conclusion that both bacterial and microalgal communities change their genotypic structure and adapt to new conditions without a drastic impact on their biodiversity. It is also important that higher nutrient concentrations have had a positive impact on the changeability of bacterial biocenosis. In the case of microalgae, environmental conditions such as water temperature and insolation play a major role. Nutrients promote algal bloom, which was higher in system "B", but this only appears in favourable conditions. Last season was dedicated to preliminary studies, to identify the main dependences and to observe how dynamically the ecosystem will be changing. The next step will be to systematically increase the load of nutrients in both systems and monitor the influence of a dynamically changed nutrient concentration on the biological balance in experimental ecosystems.

\section{Acknowledgements}

This research was partly supported under Applied Research Programme of the National Centre for Research and Development (IntegrAqua, contract No. PBS1/A8/6/2012). 


\title{
References
}

[1] Lürling M, van Oosterhout F. Controlling eutrophication by combined bloom precipitation and sediment phosphorus inactivation. Water Res. 2013;47:6527-6537. DOI: 10.1016/j.watres.2013.08.019.

[2] Cole JJ, Findlay S, Pace ML. Bacterial production in fresh and saltwater ecosystems: a cross-system overview. Mar Ecol Prog Ser. 1988;43:1-10.

[3] Cho BC, Azam F. Biogeochemical significance of bacterial biomass in the ocean's euphotic zone. Mar Ecol Prog Ser. 1990;63:253-259.

[4] Muyzer G, Smalla K. Application of denaturing gradient gel electrophoresis (DGGE) and temperature gradient gel electrophoresis (TGGE) in microbial ecology. Anton Leeuw Int J G. 1998;73(1):127-141.

[5] Casamayor EO, Schäfer H, Baneras L, Pedros-Alió C, Muyzer G.. Identification of and spatio-temporal differences between microbial assemblages from two neighboring sulfurous lakes: comparison by microscopy and denaturing gradient gel electrophoresis. Appl Environ Microb. 2000;66(2):499-508. DOI: 10.1128/AEM.66.2.499-508.2000.

[6] Berdjeb L, Ghligione JF, Jacquet S. Bottom-up versus top-down control of hypo- and epilimnion free-living bacterial community structures in two neighboring freshwater lakes. Appl Environ Micob. 2011;77(11):3591-3599. DOI: 10.1128/AEM.02739-10.

[7] Bukowska A, Bielczyńska A, Karnkowska A, Chróst RJ, Jasser I. Molecular (PCR-DGGE) versus morphological approach: analysis of taxonomic composition of potentially toxic cyanobacteria in freshwater lakes. Aquatic Biosystems. 2014;10(2). DOI: 10.1186/2046-9063-10-2.

[8] Boutte C, Grubisic S, Balthasart P, Wilmotte A. Testing of primers for the study of cyanobacterial molecular diversity by DGGE. J Microbiol Meth. 2006;65:542-550. DOI: 10.1016/j.mimet.2005.09.017.

[9] Muyzer G, de Waal EC, Uitterlinden AG. Profiling of complex microbial populations by denaturing gradient gel electrophoresis analysis of polymerase chain reaction-amplified genes coding for 16S rRNA. Appl Environ Microb. 1993;59(3):695-700.

[10] Diez B, Pedros-Alio C, Marsh TL, Massana R. Application of denaturing gradient gel electrophoresis (DGGE) to study the diversity of marine picoeukaryotic assemblages and comparison of DGGE with other molecular techniques. Appl Environ Microb. 2001;67(7):2942-2951. DOI: 10.1128/AEM.67.7.2942-2951.2001.

[11] Eland LE, Davenport R, Mota CR. Evaluation of DNA extraction methods for freshwater eukaryotic microalgae. Water Res. 2012;46:5355-5364. DOI: 10.1016/j.watres.2012.07.023.

[12] Jeremiason JD, Eisenreich SJ, Paterson MJ, Beaty KG, Hecky R, Elser JJ. Biogeochemical cycling of PCBs in lakes of variable trophic status: a paired-lake experiment. Limnol Oceanogr. 1999;44(1):889-902.

[13] Schmalenberger A, Tebbe CC. Bacterial diversity in maize rhizosphere: conclusions on the use of genetic profiles based on PCR-amplified partial small subunit rRNA genes in ecological studies. Mol Ecol. 2003;12(1):251-261. DOI: 10.1046/j.1365-294X.2003.01716.x.

[14] Schauer M, Massana R, Pedros-Alió C. Spatial differences in bacterioplankton composition along the Catalan coast (NW Mediterranean) assessed by molecular fingerprinting. FEMS Microbiol Ecol. 2000;33(1):51-59. DOI: 10.1111/j.1574-6941.2000.tb00726.x.

\section{ANALIZA BIORÓŻNORODNOŚCI BIOCENOZY BAKTERYJNEJ I GLONOWEJ W SILNIE OBCIĄŻONYCH STAWACH HODOWLANYCH}

\author{
${ }^{1}$ Katedra Biotechnologii Środowiskowej, Politechnika Śląska w Gliwicach \\ ${ }^{2}$ Instytut Ichtiobiologii i Gospodarki Rybackiej PAN w Gołyszu
}

\begin{abstract}
Abstrakt: Aktualny stan zbiorników i cieków wodnych budzi wiele zastrzeżeń. Jednym z poważniejszych zagrożeń dla ekosystemów wodnych jest zjawisko eutrofizacji, polegające na nadmiernym wzbogacaniu wody w pierwiastki biogenne. Aby chronić systemy wodne przed tym zjawiskiem, konieczne jest określenie mechanizmów jego powstawania. Z tego względu istnieje potrzeba badania zależności pomiędzy parametrami fizykochemicznymi wody, a także ich wpływu na różnorodność życia biologicznego, zwłaszcza na zmiany struktury mikrobiocenoz. Bakterie oraz mikroglony występujące w wodach są bardzo interesującymi grupami organizmów ze względu na rolę, jaką pełnią w zachowaniu homeostazy środowiska wodnego. Na ich liczebność i strukturę genotypową w znacznym stopniu wpływa nadmierne użyźnianie zbiorników wodnych. Stąd też badania złożoności takich mikrobiocenoz bakteryjnych i glonowych w aspekcie zmian spowodowanych
\end{abstract}


eutrofizacją są konieczne i uzasadnione. W pracy przedstawiono analizę bioróżnorodności biocenozy bakteryjnej oraz mikroglonów eukariotycznych w dwóch sztucznych ekosystemach wodnych - rybnych stawach hodowlanych. Akwakultura oparta była o technologię IMTA (ang. Integrated Multi-Trophic Aquaculture), w której każdy człon łańcucha pokarmowego pełni ważną rolę w zachowaniu równowagi w ekosystemie. Dwa eksperymentalne, intensywno-ekstensywne stawy hodowlane różniły się ładunkiem biogenów i charakteryzowały podwyższonym stężeniem organicznego oraz nieorganicznego azotu i fosforu. Podczas sezonu wegetacyjnego w systemach monitorowano warunki fizykochemiczne i skład jakościowy interesujących mikrobiocenoz. Do analizy bioróżnorodności wykorzystano technikę PCR-DGGE. Wyniki badań wstępnych pokazują, że istnieje zależność pomiędzy ładunkiem związków biogennych, różnorodnością określoną poprzez Indeks Shannona-Wienera oraz ogólną kondycją systemów stawowych. Wyższe stężenia biogenów wpływały pozytywnie na rozwój bakterii i mikroglonów, nie powodując jednocześnie negatywnego wpływu na równowagę w badanym, sztucznym ekosystemie.

Słowa kluczowe: bakterie, mikroglony, bioróżnorodność, eutrofizacja, Indeks Shannona-Wienera, intensywno-ekstensywna hodowla rybacka 